\title{
Regimen Used to Treat Malignant Brain Neoplasm
}

National Cancer Institute

\section{Source}

National Cancer Institute. Regimen Used to Treat Malignant Brain Neoplasm. NCI

Thesaurus. Code C63470.

Any regimen that can be used for the treatment of malignant brain neoplasm. 